\title{
妊娠中毒症患者の凝固・線溶能*
}

一特に血小板凝集能および血清脂質を中心として一

$$
\begin{aligned}
& \text { 永山正剛** 真 木 正 博** 千 葉 敦 子** } \\
& \text { 中村幸夫林野呂秀 逸** 品川信 良** }
\end{aligned}
$$

Key words : coagulation, toxemia of pregnancy, FDP, platelet aggregation, serum lipid.

はじめに

妊婦の血液の凝固学的な特徵として, 凝固元 進状態，線溶抑制状態および高脂血状態などが あげられ，血管内血液凝固が発生しやすい状態 にあると考えられている. 特にいわゆる晚期妊 娠中毒症患者の重症な場合には, 凝固能の異常 亢進を示すととがかなり以前から私たちの教室 でも血栓弾性図などで認めてきた ${ }^{1)}$.

さらに一方また McKay ら²)が主張している ように子癎の発生機序を血管内血液凝固という 立場から説明する考え方ああるため，私たちは このたび，妊娠中毒症患者の血液凝固能を，凝 固第 1 相に関与する血小板機能の面から主とし て検討し他の凝固検査成績とも対比してみた.

\section{I. 対象および方法}

検査対象としては当科および関連病院に入院 中の妊娠中毒症患者18例（中毒症の診断は日本 産科婦人科学会中毒症委員会分類に従ったが， 単に下腿に軽度の浮腫だけというような半ば生 理的浮腫とでも称し得るようなものは除外し た.) および対照として妊娠後半期 (8〜10か月) の正常妊婦30例を at random に選んだ.

検査方法は下記のあのについて行なった。

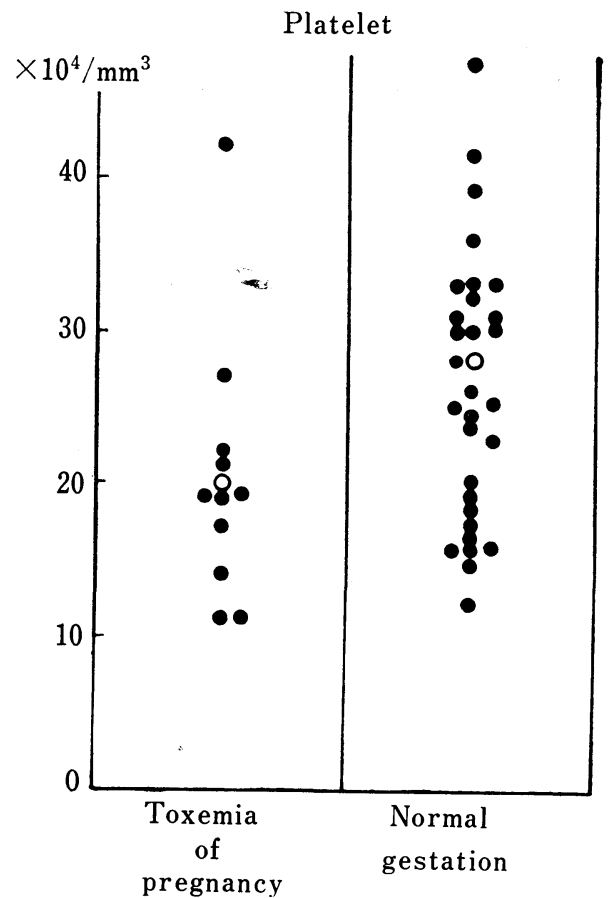

Fig. 1 Platelet Count in Normal and Toxemic Pregnancies.

1）血小板数…...Brecher-Kronkite 法.

2）血小板凝集能…... Bryston 社アグリゴ メーターにより ADP に対する凝集能測定.

3）血清 FDP 值……HAIR 法.

4）血清脂質……リグリセライド，総コ レステロール，リン脂質，過酸化脂質.

* Coagulation studies in toxemia of pregnancy with special reference to the platelet aggregation and serum lipids. (The 4th Congress of the Japanese Society on Thrombosis and Hemostasis, Nov. 28, 1975.)

** 弘前大学医学部産婦人科〔干036 弘前市相良町 2 〕, Masataka NAGAYAMA, Masahiro MAKI, Atsuko CHIBA, Yukio NAKAMURA, Shuitsu NORO \& Shinryo SHINAGAWA: Department of Obstetrics and Gynecology, School of Medicine, Hirosaki University, Aomori, Japan. 
Table 1 Platelet Count and ADP Induced Aggregation Indexes in Normal and Toxemic Pregnancies (Mean \pm S.D.).

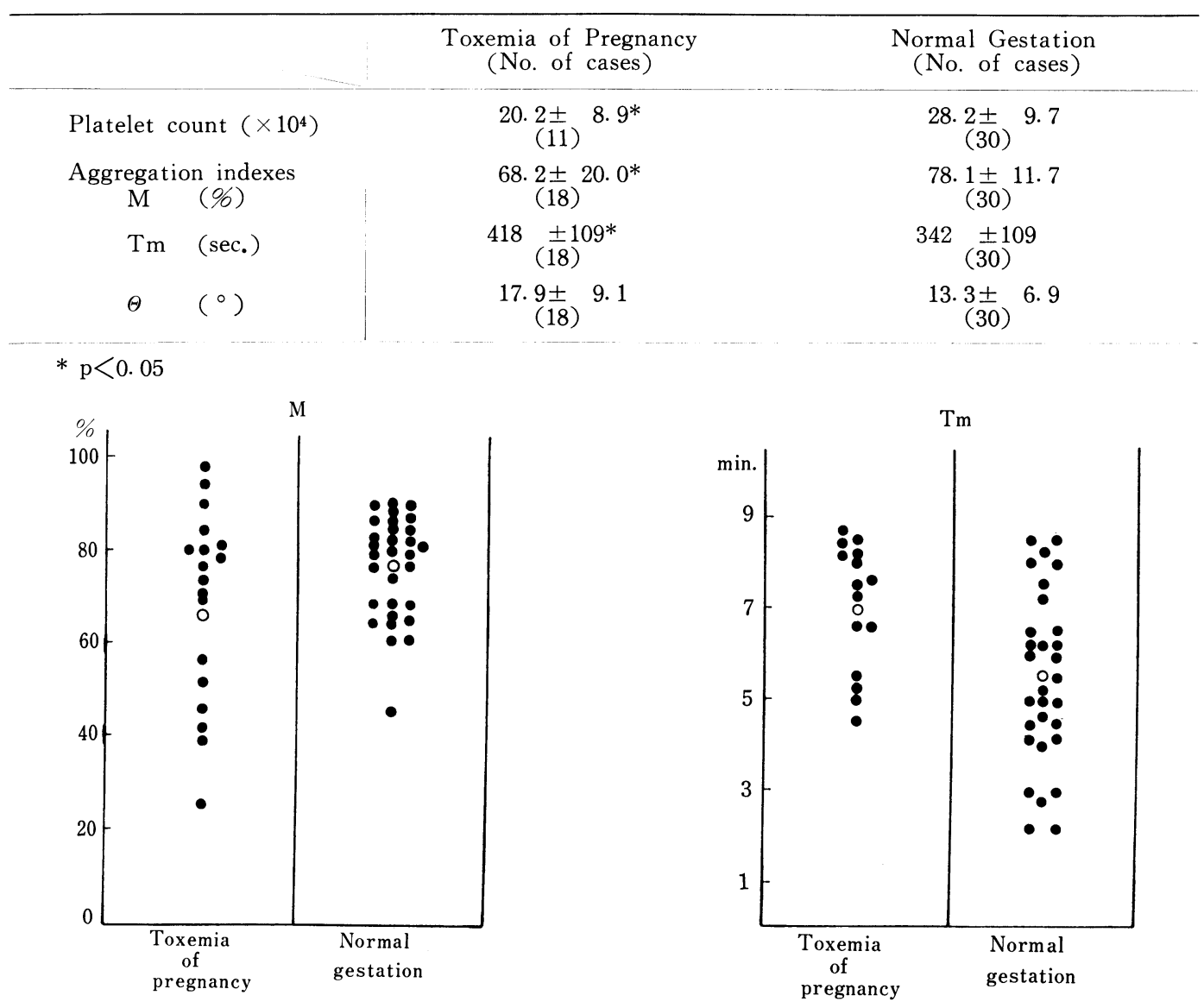

Fig. 2 Maximal Aggregation Rate in Normal and Toxemic Pregnancies.

(Malonyldialdehyde 量として)

\section{II. 成 績}

\section{1. 血小板 数}

妊娠中毒症 11 例について行なったが，平均 $20.2 \pm 8.9 \times 10^{4} / \mathrm{mm}^{3}$ であった（土以下標準偏 差). 妊娠後半期の正常妊娠 30 例では平均 28.2 $\pm 9.7 \times 10^{4} / \mathrm{mm}^{3}$ であり推計学的にも $5 \%$ の危 険率で妊娠中毒症例の方が血小板数は少なかっ た（表 1, 図 1).

\section{2. 血小板凝集能}

血小板凝集曲線の評価および比較には論議も 多いがとりあえずてれまで一般に行なわれてき た最大凝集率(以下Mと略), 最大凝集に達する までの時間 (以下 Tm と略) および初期凝集角
Fig. 3 Reaction time ( $\mathrm{Tm}=$ time between the addition of ADP and the influction in the curve) in Normal and Toxemic Pregnancies.

度（以下 $\theta$ と略）をむって表現した。

妊娠中毒症例18例のMの平均值は $68.2 \pm 20 \%$ であり, Tm の平均は $418 \pm 109$ 秒および $\theta$ の 平均は $17.9 \pm 9.1$ 度を示していた。

対照の妊娠後半期正常妊婦 30 例におけるこれ らの值はそれぞれ， $\mathrm{M}=78.1 \pm 11.7 \%, \mathrm{Tm}=$ $342 \pm 109$ 秒および $\theta=13.3 \pm 6.7$ 度であった。

Mは中毒症例で減少しており，Tm の時間む 中毒症例で延長していた。これらは推計学的に あ有意の差を示した， $\theta$ では中毒症例の方が大 きかったが有意差ではなかった。しかし全体と してみると, 凝集能は中毒症例で低下の傾向が 認められた（表 2, 図 2,3). 


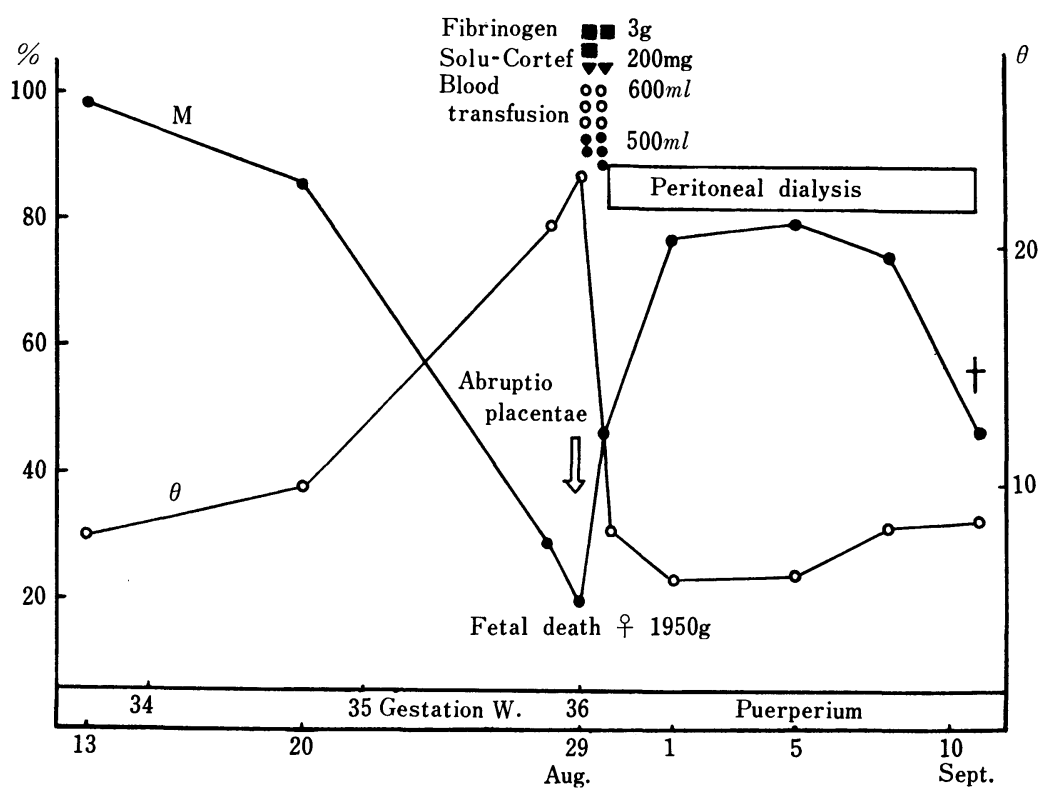

Fig. 4 Clinical Course and Serial $M \& \theta$ Curves in a Case of Abruptio Placentea.

重症妊娠中毒症にて治療中に常位胎盤早期剝 離を発生した 1 例を経験したが，出血性ショッ ク時に著明な血小板機能の低下を認めた（図 4 ).

\section{3. 血清 FDP 值}

妊娠中毒症18例については $80 \mu \mathrm{g} / \mathrm{m} l$ 以上の 陽性例が 5 例 $(27.8 \%)$ より最高 $1280 \mu \mathrm{g} / \mathrm{ml}$ の あの屯 1 例認められた. 一方対照正常妊婦では 2 例 (8.7\%) であり最高であ $160 \mu \mathrm{g} / \mathrm{m} l$ であっ た。妊娠中毒症例では FDP 陽性率が高く線溶 六進の事実のあったととを示するのと思われ る。

\section{4. 血清脂質}

1）トリグリセライド：妊娠中毒症例 9 例に ついて検査を計なったが平均值は $338 \mathrm{mg} / \mathrm{d} l$ で あった。妊娠後半期正常妊婦31例のそれは 222 $\mathrm{mg} / \mathrm{d} l$ を示していた.

2）総コレステロール：妊娠中毒症 9 例では 平均 $284 \mathrm{mg} / \mathrm{d} l$ であり, 妊娠後半期正常妊婦で は $242 \mathrm{mg} / \mathrm{d} l$ であった。

3）リン脂 質: 妊娠中毒症 9 例の平均值は $393 \mathrm{mg} / \mathrm{d} l$ であるが妊娠後半期正常妊婦のそれ は $307 \mathrm{mg} / \mathrm{d} l$ であった。

4）過酸化脂質 : Malonyldialdehyde 量を屯
ってその指標としたが，妊娠中毒症 9 例での平 均値は $16.1 \mathrm{nmol} / \mathrm{ml}$ を示していた。 以上血清 脂質は全般的に中毒症例が高值を示していた。

\section{III. 考案}

血管内血液凝固が妊娠中毒症の原因あるいは 二次的変化であり得るとの考えはPritchard ${ }^{3)} や$ Kaeser4) の報告にあみられるが, McKay らがモ デル実験でこれを立証した業績は高く評価され る.

血小板数に関して最近の Davidson ${ }^{6)}$ らの報 告によると中毒症重症例で著明に減少しており 26例中 6 例（23\%）は10万以下であったとして いる．私たちの成績でも妊娠後半期の正常妊娠 に比して明らかに減少しており，DIC の指標 の一つとされる血小板減少は確かに認められた が10万以下の減少例は臨床経過中に常位胎盤早 期剝離を起こした 1 例で早剝発症時に認められ たあののみであった。

血小板機能については粘着能は六進するとの 報告があり凝集能むまた六進を示したといわれ ている.しかし私たちの今回の成績ではむしろ 全般的にみて低下の傾向を示していた。乙れは ひとつには中毒症例では血中 FDP の増加が認 
められることからあるいは FDP による凝集阻 止によるあのかあ知れない. しかし一方血小板 数減少のことを考慮するならば，凝集能のよい 血小板はすでに採血後凝集を起こしてしまい遠 心時にこれらが除かれるために残った凝集能の 悪い血小板のみが測定されるという場合もあり うることを念頭におかねばならないと思う。

妊娠中毒症時に線維素原量やプラスミノーゲ ンは増加するとの報告が多く，FDP むまた一 般に増加が認められるようである。私たちの教 室ではすでに線維素原量やプラスミノーゲン量 が増量することを報告を行なっているが, FDP についてもやはり 今回の成績の如く増加を認 め, しかむなかには $1280 \mu \mathrm{g} / \mathrm{ml}$ の高值を示し た 1 例むあった。妊娠時には高脂血症を呈する ことが知られているが，乙れは病的なあのでは なくむしろ生理的変化ともされている.しかし 妊娠中毒症時や糖尿病では異常な高値を示すと との報告がある.とれらの変化が妊娠中毒症時 の凝固能や血小板機能との関連の深いととを考 えて，私たちも血清脂質を測定してみたが，例 数はまだ少ないがトリグリセライド，総コレス テロール，燐脂質，過酸化脂質いずれあ中毒症 で高值を示していた。

\section{総括および結論}

（1）血小板数は妊娠中毒症例では減 少してい た。

（2）血小板凝集能では中毒症例において，最大 凝集率の減少，最大凝集に至る時間の延長お よび初期凝集角の增大などを認め全体として 凝集能低下の傾向がうかがわれた。

（3）経過中，常位胎盤早期剝離を併発した 1 例 では特に著明な凝集能低下を認めた。

（4） FDP 值は中毒症例で増加を認めた。 これ は血小板凝集阻害とも関連するものと思われ る。

（5）血清脂質は全般的に著明な増加が認めら れ, 過酸化脂質の増加傾向屯認められた。

本研究の要旨は第 4 回血栓および止血に関する 討議会において発表した。発表の機会を与えられ た帝京大学安部 英教授に深謝します。

\section{文献}

1）品川信良：“分婏と出血”金原出版，東京， 1970.

2) McKay, D.G., and Goldberg, V.E.: Pathogenesis of anatomic changes in experimental toxemia of pregnancy.: Obstet. Gynecol., $21 ; 651 \sim 658,1963$.

3) Pritchard, J.A., Weisman R. Jr., Ratnoff, O.D. and Vosburgh, G.J.: Intravascular hemolysis, thrombocytopenia and other hematologic abnormalities associated with severe toxemia of pregnancy. N. Engl. J. Med., 250; 89 98, 1954.

4) Kaeser, O.: Das haemorrhagische Syndrom in der Geburtshilfe: Schweitz. Med. Wochenschr., 86; 991 996, 1956.

5) Davidson, E.C.Jr. and Phillips, L.L.: Coagulation studies in the hypertensive toxemia of pregnancy. Am. J. Obstet. Gynec., 113; 905 910,1972.

\section{$<$ ABSTRACT $>$}

\section{Coagulation Studies in Toxemia of Pregn-} ancy with Special Reference to the Platelet Aggregation and Serum Lipids

by

Masataka NAGAYAMA, Masahiro MAKI, Atsuko CHIBA, Yukio NAKAMURA, Shuitsu NORO and Shinryo SHINAGAWA from

Department of Obstetrics and Gynecology, School of Medicine, Hirosaki University, Hirosaki, Japan.

Disseminated intravascular coagulation has been suggested as a cause or an important secondary mechanism in toxemia of pregnancy. In order to clarify this evidence platlet count, aggregation, FDP, and serum lipids were studied on 30 normal pregnant women and 18 women with severe toxemia of pregnancy.

The following results were obtained:

1. The platelet count decreased slightly in severe toxemia of pregnancy as compared with the third trimester of normal pregnancy.

2. In severe toxemia of pregnancy, the rate of platelet aggregation induced by ADP was 
$8: 538$

lower than of normal pregnancy.

3. In one case with abruptio placentae, platelet aggregation rate had fallen considerably at the time of hemorrhagic shock.
血 液 と脈 管 第 8 巻 第 4 号

4. FDP and serum lipids levels showed a marked increase in severe toxemia of pregnancy than in third trimester of normal pregnancy. 